\title{
Effect of Exogenous Enzymes on Egg Fertility Traits, Egg Production and Oviduct Micro-structure of Layer Birds
}

\author{
Chibuogwu I. C. ${ }^{1 *}$, Agubosi O. ${ }^{2}$, Oladipo B. T. ${ }^{2}$ \\ ${ }^{\prime}$ Department of Theriogenology, Faculty of Veterinary Medicine, University of Abuja, Nigeria \\ ${ }^{2}$ Department of Animal Science, Faculty of Agriculture, University of Abuja, Nigeria.
}

Accepted June, 2021 and Published July, 2021

\begin{abstract}
The effect of two classes of exogenous enzymes on the egg fertility traits, egg production efficiency and oviduct micro-structure of laying hens was evaluated. Forty-five laying hens (30-weeks old, $1.32-1.40 \mathrm{~kg}$ ) were randomly allotted into three dietary treatments with fifteen birds per treatment (five birds each in three replicates per treatment) in a completely randomized design. Diet one served as the control diet. Diet two (FS diet) contained a nutrient-targeted exogenous enzyme preparation (Fullzyme $\left.{ }^{\circledR}\right)$ at $200 \mathrm{~g} / \mathrm{ton}$, while diet three (DS diet) contained a mycotoxin-targeted exogenous enzyme preparation (Detoxizyme ${ }^{\circledR}$ ) at $500 \mathrm{~g} / \mathrm{ton}$. Data on fertility traits (egg volume, length and breadth, weight, yolk diameter, albumen height, air cell, shell thickness, Haugh's unit, and egg-lay), and egg production (feed intake, egg lay, egg lay efficiency, and feed cost per egg laid) were collected for 42 days. At the end of the experiment, three randomly selected birds per group were euthanized, and their oviducts were harvested and processed for histopathology. Hens fed enzyme supplemented diets had significantly $(p<0.05)$ better egg fertility traits. Feed intake in the control group did not vary ( $p>0.05)$ from feed intake in the DS or FS group. However, feed cost per egg laid and egg-lay efficiency was higher in the control diet group than in the FS group or DS diet group. No pathologies were observed in the oviduct of birds fed enzymes supplemented or control diet. Exogenous enzymes in diet improved egg fertility traits and production without altering the oviduct micro-structure of Layer hens.
\end{abstract}

Keywords: Exogenous enzymes, fertility traits, Egg production, oviduct histology

\footnotetext{
*Corresponding author:

email: ijeoma.chibuogwu@uniabuja.edu.ng

Tel: +234-8036943285
} 


\section{INTRODUCTION}

The fertility of a female animal is closely associated with its nutritional plane. Fertility may be defined as the ability of the female animal to have the desire to mate or be mated, to mate, conceive, maintain the conceptus to term and successfully produce a viable offspring of its kind. In mammals, the developing conceptus depends on the dam's uterine environment for its nutrition and nurturing up to full term. In avian species, the nutritional requirement of the conceptus is extracted from the blood supply of the reproductive system into the egg. Thus, the nutritional status of the hen is critical in determining the nutritional content of the egg. The developing chick usurps the egg's nutritional content as the egg is incubated outside the hen's reproductive tract and is an essential determinant of fertility. A bird's dietary protein and energy levels influence its fertility and laying performance [1][2][3][4]. The ovary and oviduct are the hen's reproductive organs responsible for egg formation and depositing the chick's nutritional requirement within the egg. The micro-structure of the functional sections of the oviduct may give an insight into the effect of a substance on the bird's egg formation process.

The introduction of exogenous enzymes in animal feed has recorded many benefits in animal reproduction. Exogenous enzymes may be nutrient targeted exogenous enzymes or mycotoxin-targeted exogenous enzymes. In poultry production, the application of nutrient targeted exogenous enzymes improves digestibility and feed conversion ratio. For instance, nutrient targeted amylolytic enzymes breakdown starchy foods by dislodging glycosidic bonds and releasing more glucose units that can be converted to energy [5]; proteolytic enzymes release amino acids by disrupting nitrogen bonds in proteinous foods or cell walls of forages[6], while fibrinolytic enzymes digest insoluble non-starch polysaccharides like cellulose and hemicellulose found in most feedstuffs of plant origin [7].

Anti-mycotoxin exogenous enzymes are incorporated in feed or feed additives to deactivate, modify or attenuate toxins produced by fungi that contaminate feed and feedstuff. In Nigeria, pathogenic mycotoxin commonly found in poultry feed include aflatoxins, ochratoxin A, Fumonisin B1, T2-toxin, nivalenol, deoxynivalenol [8]. Mycotoxins decrease the activity of several digestive enzymes and enzymes involved in nucleic acid metabolism and impair immunological functions [9][10]. In poultry, it reduces the absorptive capacity of the intestinal mucous membrane [11] and narrows the surface area of the intestinal villus [12]. In layer birds, mycotoxins are known to reduce egg weight [13], feed intake, egg production and eggshell thickness [14]. Mycotoxins in diet may be controlled by enzymes that degrade and transform the molecular structure of nonabsorbable mycotoxins into non-toxic forms [15] and by detoxification using nutritionally inert adsorbents to bind and immobilize mycotoxins in the gastrointestinal tract of animals, reducing their bioavailability [16].

Fullzyme ${ }^{\circledR}$ is a nutrient targeted exogenous enzyme preparation, while Detoxizyme ${ }^{\circledR}$ is a mycotoxin targeted exogenous enzyme preparation. In sows, the administration of Detoxizyme ${ }^{\circledR}$ ameliorates production loss due to mycotoxicosis and improves fetal implantation [17]. Poultry farmers within the local community often incorporate Fullzyme ${ }^{\circledR}$ and Detoxizyme ${ }^{\circledR}$ to boost egg production with varying successes.

This research aimed to assess the effect of Fullzyme ${ }^{\circledR}$ and Detoxizyme ${ }^{\circledR}$ supplemented in layer diet on egg fertility traits and oviduct micro-structure, and egg production, and to estimate the economic advantage as feed supplements.

\section{MATERIALS AND METHODS}

The experiment was carried out at the University of Abuja Teaching and Research Farm, Animal Science Section, Main Campus, along Airport Road, Gwagwalada, Abuja-Nigeria. Gwagwalada is located between latitude $8^{0} 57^{1}$ and $8^{0} 55^{\mathrm{I}} \mathrm{N}$ and longitude $7^{\circ} 05^{\mathrm{I}}$ and $7^{\circ} 06^{\mathrm{I}} \mathrm{E}$, and has temperature ranges of $28^{\circ} \mathrm{C}-33^{\circ} \mathrm{C}$ during the day time and $22^{\circ} \mathrm{C}-25^{\circ} \mathrm{C}$ at night 


\section{Preparation of Experimental Diets}

Feed ingredients were procured from a reputable agro-vet shop and formulated into three maizebased experimental diets, as shown in Table 1. Diet one (Control diet) was the control without the inclusion of enzymes. Diet two (FS diet) contained Fullzyme ${ }^{\circledR}$ (Biofeed Technology Incorporated, Brossard Canada) at $200 \mathrm{~g} /$ ton of feed as prescribed by the manufacturer. Diet three (DS diet) contained Detoxizyme (Polchem Hygiene laboratories PVT Ltd., Pune, India) at $500 \mathrm{~g} /$ ton of feed and as indicated by the manufacturer. The proportion of ingredients and calculated chemical composition of the ingredients are shown in Table 1.

\section{Experimental Animals and Management}

Laying hens of 30 weeks old were kept in pens that were well disinfected before their arrival. On arrival, they were administered anti-stress in their drinking water, and standard management practices of sanitation were carried out. Fresh water and feed were provided ad-libitum, and the birds were exposed to a steady 12 hours light, 12 hours dark period per day.

\section{Experimental Design}

Forty-five (45) laying hens of 30 weeks old and body weight range of $1.32-1.40 \mathrm{~kg}$ were randomly allotted into the three (3) dietary groups in a completely randomized design (CRD) experiment. Each treatment was replicated thrice with five birds (5) birds per replicate (Tables 2 and 3 ). The eggs were collected and assessed for a period of 42 days. At the end of the experiment, three birds from each group were randomly selected and euthanized. Their oviducts were harvested, blotted on paper, and preserved in $10 \%$ formalin and processed for histopathology

\section{Outcome Measure}

\section{Egg characteristics}

Average parameters from six randomly selected eggs from each group were recorded daily for 42 days (six weeks)
Egg Volume: Egg length and breadth (at widest circumference in millimetres was measured with a vernier calliper. Volume was then calculated as $\mathrm{V}=(0.6057-0.0018 \mathrm{~B}) \mathrm{LB}^{2}$ [18]. Where ' $\mathrm{V}$ ' is volume, ' $\mathrm{L}$ ' is egg length and ' $\mathrm{B}$ ' is egg breadth. The average volume of eggs from each treatment group was then compared.

\section{Egg weight}

The average egg weight in each treatment group was measured by dividing the total weight of the eggs laid by the number of eggs laid in each week.

\section{Egglay}

Egg laid from each treatment group was collected daily and recorded.

\section{Egg production parameters}

\section{Egglay}

The number of eggs laid by 15 birds in each group per day were noted and recorded.

\section{Feed intake}

Feed intake was measured as the difference between the weight of feed served and the weight of feed remnant recovered daily.

\section{Egg lay efficiency}

Egg lay efficiency (EPE) for 15 birds per group was calculated as Daily feed intake / Eggs laid per day X a dozen eggs ( $\mathrm{kg} / 12$ eggs laid/day)

\section{Feed cost per egg laid}

Feed cost per egg laid was calculated as average cost ( $)$ of feed consumed daily /average daily egg lay per group.

\section{Fertility traits of eggs}

Daily, six (6) eggs from each treatment group were randomly selected and cracked open at the equatorial region. The following parameters were measured, and a daily average value was recorded:

\section{Yolk diameter}

Contents of cracked-open eggs were poured onto a glass slab, and the diameter of the yolk was measured with a vernier calliper (iGaging 
ABSOLUTE ORIGIN 6" digital Caliper, California, USA).

\section{Albumen height}

Distance from the base of glass slab to the surface of the albumen was measured with a micrometre screw gauge (Eisco Labs 0-25x 0.01 mm Micrometer Screwgauge, India);

\section{Air cell height}

The egg was positioned with the air space facing upwards, and the interior was observed by candling. The height of the air cell was marked on the shell. The height was then measured using the digital calliper.

\section{Shell thickness}

Eggshell was washed and dried. Shell was measured using the micrometre screw gauge at three different points at the equatorial region, and the average was taken.

\section{Haugh's unit}

Haugh's Unit was calculated using Cotta's [19] formula: $\mathrm{HU}=100 \log \left(\mathrm{h}-1.7 \mathrm{w}^{0.37}+7.6\right) . \mathrm{HU}=$ Haugh unit, $\mathrm{h}=$ albumen height $(\mathrm{mm})$ and $\mathrm{w}=$ egg weight $(\mathrm{g})$.

\section{Oviduct micro-structure}

Cross-sections of the infundibulum, magnum (ampulla), isthmus, uterus and vagina of birds were processed by routine hematoxylin and eosin technique.

The oviduct of birds from the control diet group was compared qualitatively to birds from the FS diet and DS diet groups.

\section{RESULTS}

Fertility Traits of Eggs from Laying Birds Fed Exogenous Enzymes

Egg characteristics of Laying birds fed exogenous enzymes

All the egg characteristics parameters of the birds fed diets supplemented with exogenous enzymes (FS and DS diets) were significantly different $(\mathrm{P}<0.05)$ from eggs of birds fed the control diet (Fig. 1).
The length and width of the eggs from birds fed enzyme supplemented diet differed significantly $(p<0.05)$ from eggs of birds fed the control diet (Fig. 1a-b). The eggs from birds fed the control diet had the shortest egg length $(5.31 \pm 0.08 \mathrm{~cm})$ and width $(4.14 \pm 0.09 \mathrm{~cm})$ followed by eggs from birds fed DS diet $(5.44 \pm 0.12 \mathrm{~cm} ; 4.19 \pm$ $0.08 \mathrm{~cm}$, respectively) while the eggs from birds fed the FS diet had the most extended length $(5.50 \pm 0.11 \mathrm{~cm})$ and width $(4.23 \pm 0.07 \mathrm{~cm})$.

There was a significant $(\mathrm{P}<0.05)$ difference in the egg volume and weight of laying birds fed selected enzymes (Fig. 1c-d). The birds fed the control diet laid eggs with the smallest volume $\left(48.40 \pm 2.37 \mathrm{~cm}^{3}\right)$ and lightest weight $(52.74 \pm$ $0.98 \mathrm{~g}$ ), followed by eggs from the birds fed DS diet group $\left(50.66 \pm 2.66 \mathrm{~cm}^{3} ; 54.64 \pm 1.62 \mathrm{~g}\right.$, respectively), while eggs from the birds fed FS diet had the most significant volume $(52.13 \pm 2.4$ $\left.\mathrm{cm}^{3}\right)$ and heaviest weight $(56.78 \pm 1.87 \mathrm{~g})$.

\section{Quality of eggs from Laying birds fed exogenous enzymes}

There were significant variations $(\mathrm{P}<0.05)$ in egg quality between eggs from birds fed FS or DS diets and eggs from birds in the control diet group (Fig. 2).

The egg yolk diameter and Haugh's unit (Fig. 2a, $2 \mathrm{~b}$ respectively) of eggs from the birds fed FS diet $(32.94 \pm 0.88 \mathrm{~mm} ; 78.63 \pm 1.10$ respectively) was higher than eggs from birds fed the control diet $(32.41 \pm 0.86 \mathrm{~mm} ; 76.43 \pm$ 2.80 , respectively) or the DS diet (32.52 \pm 0.56 $\mathrm{mm} ; 76.84 \pm 1.46$, respectively. The egg yolk diameter and Haugh's Unit of eggs from birds fed the control diet were similar to eggs from birds fed the DS diet.

The shell thickness and albumin height of eggs ( Fig. 2 c, 2 d respectively) were least in the birds fed the control diet $(0.31 \pm 0.05 \mathrm{~mm} ; 5.60 \pm 0.37$ $\mathrm{mm}$ respectively), followed by the eggs from the birds fed the DS diet $(0.37 \pm 0.05 \mathrm{~mm} ; 5.74 \pm$ $0.23 \mathrm{~mm}$, respectively) but highest in the eggs from birds fed the FS diet $(0.41 \pm 0.04 \mathrm{~mm} ; 6.09$ $\pm 0.19 \mathrm{~mm}$, respectively). 
There was no significant variation $(\mathrm{P}>0.05)$ in the air cell height of eggs laid by birds given the control diet or exogenous enzyme supplemented diets (Fig. 2d).

\section{Egg Production Parameters of Layer Birds Fed Selected Enzymes}

The formulated feed efficiency in egg production with or without exogenous enzymes and the costeffectiveness of the formulated feed is presented in Fig. 3.

A significant variation $(\mathrm{P}<0.05)$ was observed in the daily egg-lay of the birds fed exogenous enzymes, and the birds fed the control diet (Fig.3a). The birds fed FS diet (12.24 \pm 0.47 eggs/ 15 birds/day) and DS diet (12.19 \pm 0.47 eggs/ 15 birds/day) laid more daily eggs than the birds fed the control diet $(10.57 \pm 0.25 \mathrm{eggs} / 15$ birds/day). The egg lay in the FS diet group was similar to the egg lay in the DS diet group.

The daily feed intake varied significantly $(\mathrm{p}<$ 0.05 ) among the different groups. The daily feed intake of birds was highest in the DS diet group $(1.8209 \pm .0009 \mathrm{~kg} / 15 \mathrm{birds})$, followed by the FS diet group (1.8192 $\pm 0.0007 \mathrm{~kg} / 15$ birds ) while the daily feed intake of birds in the control diet group $(1.8198 \pm 0.0010 \mathrm{~kg} / 15 \mathrm{birds})$ was similar to both groups.

There were significant variations $(\mathrm{P}<0.05)$ in the Egg lay efficiency (feed intake per a dozen egg laid) and Feed cost per egg laid between the birds fed the control diet, and the birds fed the enzyme supplemented diets (Fig. $3 \mathrm{c}$ and 3d). Egg lay efficiency and feed cost per egg laid was higher in the control diet group $(2.07 \pm 0.05$ and $31.00 \pm$ $0.30 \mathrm{~N}$, respectively) than in the FS diet group $(1.79 \pm 0.07$ and $26.79 \pm 0.43 \mathrm{~N}$, respectively) or the DS diet group ( $1.79 \pm 0.07$ and $26.92 \pm 0.42$ $\mathrm{N}$, respectively). The Egg lay efficiency and feed cost per egg laid in the FS diet group were similar to the Egg lay efficiency and feed cost per egg laid in the DS diet group.

\section{Oviduct Histology}

No pathologies were observed in the oviduct of birds fed Fullzyme-supplemented, Detoxizyme- supplemented, or the control diets. Typical micrographs of sections of the ovary, infundibulum, magnum, isthmus, uterus and vagina are presented in Fig 4.

\section{DISCUSSION}

The egg characteristics and quality are fertility traits that may indicate the fertility of an avian ovum and the capacity of an egg to nourish a chick unto hatching. It may also indicate the capacity of a bird's egg to develop into a viable offspring [20]. In the current study, eggs from hens fed enzyme supplemented diet had thicker shells than eggs from hens fed the control diet. Shell thickness has been strongly associated with egg fertility. Thick-shelled eggs have better fertility and hatchability and fewer embryonic mortalities [21][22][23]. The egg yolk and albumen supply nutrients to a developing embryo and may determine egg fertility. Egg yolk diameter and albumen height are essential parameters in the breeding industry and were higher in eggs from the birds fed exogenous enzyme supplemented diets. Haugh's unit is a function of the albumen height and a measure of protein quality. Albumen height may be affected by the breed [24], age and temperature of storage [25], and diet [26]. In the current study, Haugh's unit and albumen height were greater in eggs from hens in the FS and DS diet groups. The findings in the current study differed from that of Roberts and Choct [27], who found that Haugh's unit and albumen height depreciated when exogenous enzymes were added to layers' diet. The difference between Robert and Choct [27] and the current study may be due to the different basal diets and consequently different enzymesubstrate and the spectrum of enzymes used in the studies. Robert and Choct [27] used barleybased and wheat-based diets, while a maizebased diet was used in the current study. Layers fed maize-based diet have better feed efficiency than layers fed barley-based diet [28]. Robert and Choct [27] used fewer enzymes while a broad spectrum of enzymes was used in the current study.

Air cell height did not differ among the three groups because air cell is a parameter often 
affected by storage duration. The egg quality for eggs from each dietary treatment group was determined the day each egg was laid, and deterioration could not have set in.

The egg lay efficiency, daily egg lay, and feed cost per egg lay were better in birds fed exogenous enzyme supplemented diet than birds fed the control diet. This finding suggests that the inclusion of selected enzymes in the diet of laying birds boost their egg production and that egg production is more cost-effective when layer diets are supplemented with exogenous enzymes. This finding supports the findings of Abreu et al. [29], who reported higher egg production in birds fed enzyme supplemented diet.

In the current study, the eggs from layer birds fed FS diet, or DS diet, had better egg characteristics, egg fertility traits and egg production efficiency than the layer birds fed only the control diet. Egg characteristics such as egg size, volume, and weight are chiefly influenced by the age of lay [30], the genetic makeup of the birds [31] and the protein and metabolizable energy content of diet [32]. In the current study, these factors were controlled in the design of the experiment as all the birds were from the same parent stock and brood and were fed the same basal diet with 16.6 $\%$ crude protein and $2593.03 \mathrm{Kcal} / \mathrm{Kg}$ of Metabolizable energy content (Table 1). However, the quantity of feedstuffs that supply nutrients to the bird is not an accurate measure of the nutrient available to the bird for its metabolism and egg production. Some feedstuff contains anti-nutritional factors like non-soluble polysaccharides, making nutrients in plant material unavailable for digestion and utilization in the digestive system [33]. Enzymes generally facilitate the availability and absorption of nutrients in the bird's digestive system by breaking down chemical bonds that secure nutrients within cells in plant feedstuff, thus releasing the nutrients [34]. FS diet contained Fullzyme ${ }^{\circledR}$ that is rich in protease, amylase, cellulase, lipase, B-glucanase, phytase, pectinase, and xylanase (Table 1). Perhaps the enzymes in the FS diet made more nutrients available for absorption and consequent utilization in egg production and improvement of egg quality and characteristics observed in the layers from the FS diet group. Birds in the DS diet group also performed better than birds in the control diet regarding egg characteristics, egg fertility traits, egg production, and feed cost per egg laid. DS diet contained Detoxizyme ${ }^{\circledR}$, which contains mycotoxin binding agents (Hydrated Sodium Calcium Aluminosilicate), and enzymes (Aflatoxin B1 Carbonyl Reductase, Peptidase, Epoxide reductase, Esterase and a blend of specific natural detoxifying enzyme) that deactivate, modify or attenuate toxins produced by fungi in contaminated feed and feedstuff (Table 1). In addition to causing several disease syndromes, mycotoxins may also reduce digestive enzyme activity, nutrient uptake and cause poor feed efficiency [15]. Perhaps the presence of mycotoxins limiting nutrient availability may contribute to the lower performance of birds fed the control diet since the birds fed the DS diet performed better. However, in the current study, the supplementation of diet with Detoxixyme did not result in as much improvement as supplementing the diet with Fullzyme. This finding suggests that the primary limitation to egg production, egg characteristics, fertility traits, and feed cost per egg-lay observed in the current study was the reduced availability of nutrients from anti-nutritive factors present in the compounded feed, and not due to mycotoxins.

\section{conclusion}

Nutrient-targeted and mycotoxin-targeted exogenous enzymes improved egg lay efficiency, feed cost per egg laid, egg characteristics and egg fertility traits of Layer hens when included in the diet. Nutrient targeted exogenous enzymes had special effects in laying hens and should be incorporated as an inherent component of Layer feed. In contrast, antimycotoxin exogenous enzymes may be used when necessary as a preventive or therapeutic measure against mycotoxicosis.

\section{Acknowledgements}

The authors acknowledge the entire staff of the University of Abuja Research Farm for providing some resources and a suitable environment for the research to be carried out. 


\section{REFERENCES}

1. Van Emous RA, Kwakkel RP, Van Krimpen MM, Van den Brand H, Hendriks WH. 2015. Effects of growth patterns and dietary protein levels during rearing of broiler breeders on fertility, hatchability, embryonic mortality, and offspring performance. Poultry Science, 94(4), 681-691. https://doi.org/10.3382/ps/pev024

2. Ugurlu M, Akdag F, Tek B, Salmanet M. 2017. Effects of protein in diet and sex ratio on egg production, egg and hatching chick weight, fertility, hatchability and embryonal mortality in pheasants (Phasianus Colchicus). Brazilian Journal of Poultry Science, 19(2), 231-238 [Accessed 29 June $\left.2 \begin{array}{lll}2 & 2 & 1\end{array}\right]$ A v a i 1 a b 1 e f r o m : $<$ https://doi.org/10.1590/1806-9061-2016$\begin{array}{lllll}0 & 4 & 2 & 3 & >\end{array}$. I S S N $18006-90661$. https://doi.org/10.1590/1806-9061-2016$\underline{0423}$

3. Saleh B, Doma UD, Kalla DJU, Mbap ST, Mohammed G. 2018. Influence of prebreeder dietary energy and protein levels on subsequent laying performance of FUNAAB - alpha chickens. Nigerian Journal of Animal Science, 20(2), 153-161.

4. Lotfi E, Karimi N, Parizadian KB, Sharifi M. 2018. Influence of different dietary levels of energy and protein on reproductive and posthatch growth performance in Japanese quails. Iranian Journal of Applied Animal Science, 8(1), 137-145.

5. Perez S, Baldwin PM, Gallant DJ. 2009. Chapter 5 - Structural Features of Starch Granules I. In: BeMiller J, Whistler R. eds., Food Science and Technology, Starch (Third Edition). Academic Press, San Diego. pp. 149-192

6. Romero LF, Sands JS, Indrakumar SE, Plumstead PW, Dalsgaard S, Ravindran V. 2014. Contribution of protein, starch, and fat to the apparent ileal digestible energy of corn- and wheat-based broiler diets in response to exogenous xylanase and amylase without or with protease. Poultry Science, 93(10), 2501-13. doi: 10.3382/ps.2013-03789

7. Alagawany M, Elnesr SS, Farag MR. 2018. The role of exogenous enzymes in promoting growth and improving nutrient digestibility in poultry. Iran Journal of Veterinary Research, 19(3), 157-164. v.19(3); Summer 2018.

8. Akinmusire OO, El-Yuguda AD, Musa JA, Oyedele OA, Sulyok M, Somorin YM, Ezekiel CN, Krska R. 2019. Mycotoxins in poultry feed and feed ingredients in Nigeria. Mycotoxin Research, 35, 149-155. https://doi.org/10.1007/s12550-018-0337y

9. Awad W, Ghareeb K, Bohm J, Zentek J. 2013. The toxicological impacts of the Fusarium mycotoxin, deoxynivalenol, in poultry flocks with special reference to immunotoxicity. Toxins (Basel), 5(5), 912925. doi:10.3390/toxins5050912

10.Huang Z, Wang Y, Qiu M, Sun L, Deng Y, Wang $\mathrm{X}$, Bi S, Gooneratne $\mathrm{R}$, Zhao J.2019.Effects of $\mathrm{T}-2$ toxin on digestive enzyme activity, intestinal histopathology and growth in shrimp Litopenaeus vannamei. Scientific Reports, 9, 13175. https://doi.org/10.1038/s41598-01949004-4

11. Osselaere A, Santos R, Hautekiet V, De Backer P, Chiers K, Ducatelle R, Croubels S. (2013). Deoxynivalenol impairs hepatic and intestinal gene expression of selected oxidative stress, tight junction and inflammation proteins in broiler chickens, but the addition of an adsorbing agent shifts the effects to the distal parts of the small intestine. PloS One, 8(7), e69014. 
$\underline{\text { https://doi.org/10.1371/journal.pone. } 00690}$ $\underline{14}$

12.Awad WA, Hess M, Twarużek M, Grajewski, J, Kosicki R, Böhm J, Zentek J. 2011. The impact of the Fusarium mycotoxin deoxynivalenol on the health and performance of broiler chickens. International Journal of Molecular Science, 12 ( 11 ) , $7996-8012$. doi:10.3390/ijms 12117996

13. Siloto EV, Sartori DRS, Oliveira EFA, Sartori JR, Fascina VB, Berto DA. 2011. Performance and egg quality of laying hens fed diets containing aflatoxin, fumonisin and adsorbent. Brazilian Journal of Poultry Scie nce, 13 ( 1), 21 - 28 . https://dx.doi.org/10.1590/S1516635X2011000100004

14.Jia R, Ma Q, Fan Y, Ji C, Zhang J, Liu T, Zhao L. 2016. The toxic effects of combined aflatoxins and zearalenone in naturally contaminated diets on laying performance, egg quality and mycotoxins residues in eggs of layers and the protective effect of Bacillus subtilis biodegradation product. Food and Chemical Toxicology, 90, 142-150. doi.org/10.1016/j.fct.2016.02.010

15. Grenier B, Applegate TJ. 2013. Modulation of intestinal functions following mycotoxin ingestion: meta-analysis of published experiments in animals. Toxins, 5(2), $\begin{array}{lllllll}3 & 9 & 6 & - & 4 & 3 & 0\end{array}$. https://doi.org/10.3390/toxins5020396

16. Murugesan GR, Ledoux DR, Naehrer K, Berthiller F, Applegate TJ, Grenier B, Phillips T D, Schatzmayr G. 2015. Prevalence and effects of mycotoxins on poultry health and performance, and recent development in mycotoxin counteracting strategies. Poultry Science, 94(6), 12981315. https://doi.org/10.3382/ps/pev075
17. B i o m i n I n t e r nat i o n a 1 . [https://www.biomin.net/species/pigs/myc otoxins/]. Assessed Novenber 112020

18. Narushin VG. 2005. Egg geometry calculation using the measurements of length and breadth. Poultry Science, 84(3), 482-4. https:doi.org/10.1093/ps/84.3.482.

19. Cotta T. 1997. Chicken Reproduction and Egg Production. UFLA-Faepe: Lavras, Brazil, 92 pp.

20. Onagbueson O, Bruggeman V, Debonne M, Witters A, Tonna K, Everaert N, Decuypere F. (2007).Gas exchange during storage and incubation of avian eggs: Effect on embryogenesis, hatchability, chick quality and post-hatching growth. World's Poultry Science Journal, 63, 557-573.

21. Roque L, Soares MC. 1994. Effects of eggshell quality and broiler breeder age on hatchability. Poultry Science, 73(12), 18381845. doi: $10.3382 / \mathrm{ps} .0731838$.

22.Narushin VG, Romanov MN. 2002. Egg physical characteristics and hatchability. World's Poultry Science Journal, 58, 297303. 10.1079/WPS20020023

23.Liao B, Qiao HG, Zhao XY, Bao M, Liu L, Zheng CW, Li CF, Ning ZH. 2013. Influence of eggshell ultrastructural organization on hatchability. Poultry Science, 92(8), $\begin{array}{lllllllll}2 & 2 & 3 & 6 & - & 2 & 2 & 3 & 9\end{array}$. https://doi.org/10.3382/ps.2012-02728

24.Lewko L, Gornowic E. 2009. Egg albumen quality as affected by bird origin. Journal of Central European Agriculture, 10(4), 455464. Accessed 23 June, 2021 from jcea104.indb (agr.hr) 
25.Barreras SA, Figueroa SF, Sanchez LE, Perez LC, Juárez CL. 2016. Temperature and shelving period effect on albumin height and color of supermarket eggs sold in northwest Mexico. Acta Universitaria, 26(4), 12-18. doi: 10.15174/au.2016.909

26.Kowalska E, Kucharska-Gaca J, Kuźniacka J, Lewko L, Gornowicz E, Biesek J, Adamski M. 2021. Egg quality depending on the diet with different sources of protein and age of the hens. Scientific Reports, 11, 2638. https://doi.org/10.1038/s41598-021$\underline{82313-1}$

27.Robert JR, Choct M. 2006. Effect of commercial enzymes preparations on egg and in laying birds. British Poultry Science, 47(4), 501-510.
28. Esubalew SA. 2019. Review on the role of enzyme supplementation on egg production performance of Layer.International Journal of Animal Husbandry and Veterinary Science, 4(5), 2455-8567. IJAHVS_49_FINAL.pdf

29. Abreu M, Fassan E, Silveira M, Viveiros M. 2018. Enzymatic complex based on xylanase, $\beta$-glucanase and phytase in rations for light commercial laying hens at peak production. Animal Industry Bulletin, 75. Accessed 23 June 2021 from http://www.iz.sp.gov.br/bia/index.php/bia/ article/view/1440

30.Joyner CJ, Peddie MJ, Taylor TG. 1987. The effect of age on egg production in the domestic hen. General and Comparative Endocrinology, 65(3), 331-336, https://doi.org/10.1016/00166480(87)90117-1. 
Table 1: Proportion (\%) of ingredients in compounded $m$ aize-based diets.

\begin{tabular}{|c|c|c|c|c|}
\hline \multirow{2}{*}{$\begin{array}{l}\text { Proportion of } \\
\text { Ingredients } \\
(\%)\end{array}$} & \multirow[t]{2}{*}{ Component } & \multicolumn{3}{|c|}{ Experimental diets } \\
\hline & & $\begin{array}{l}\text { Control } \\
\text { diet }\end{array}$ & FS diet & DS diet \\
\hline & Maize & 47 & 47 & 47 \\
\hline & $\mathrm{BDG}$ & 10.0 & 10.0 & 10.0 \\
\hline & $\mathrm{PKC}$ & 10.0 & 10.0 & 10.0 \\
\hline & GNC & 10.0 & 10.0 & 10.0 \\
\hline & SBC & 8.50 & 8.50 & 8.50 \\
\hline & Limestone & 10.0 & 10.0 & 10.0 \\
\hline & $\mathrm{BM}$ & 3.0 & 3.0 & 3.0 \\
\hline & Salt & 0.30 & 0.30 & 0.30 \\
\hline & $\begin{array}{l}\text { Exogenous } \\
\text { enzymes }\end{array}$ & 0.00 & 0.10 & 0.10 \\
\hline \multirow{13}{*}{$\begin{array}{l}\text { Total } \\
\text { Calculated } \\
\text { chemical } \\
\text { composition }\end{array}$} & Vitamin and & 0.40 & 0.30 & 0.30 \\
\hline & Minerals premix & & & \\
\hline & Lysine & 0.20 & 0.20 & 0.20 \\
\hline & Methionine & 0.30 & 0.30 & 0.30 \\
\hline & Toxin Binder & 0.30 & 0.30 & 0.30 \\
\hline & & 100 & 100 & 100 \\
\hline & $\mathrm{CP} \%$ & 16.60 & 16.60 & 16.60 \\
\hline & ME: Kcal/KG & 2593.03 & 2593.03 & 2593.03 \\
\hline & $\mathrm{CF} \%$ & 4.47 & 4.47 & 4.47 \\
\hline & $\mathrm{Ca} \%$ & 2.58 & 2.58 & 2.58 \\
\hline & $\mathrm{P} \%$ & 0.69 & 0.69 & 0.69 \\
\hline & Lysine & 0.67 & 0.67 & 0.67 \\
\hline & Methionine & 0.30 & 0.30 & 0.30 \\
\hline
\end{tabular}

FS diet= Fullzyme Supplemented diet (contains nutrient targeted exogenous enzymes) 
Table 2: Experimental animals layout

\begin{tabular}{llll}
\hline Replicate & & \multicolumn{2}{c}{ Treatment } \\
& Control diet & FS diet & DS diet \\
\hline Replicate 1 & 5 & 5 & 5 \\
Replicate 2 & 5 & 5 & 5 \\
Replicate 3 & 5 & 5 & 5 \\
Number of birds & 15 & 15 & 15 \\
per treatment & & & \\
\hline
\end{tabular}

Total number of birds used in experiment $=45$

FS diet $=$ Fullzyme Supplemented diet (contains nutrient targeted exogenous enzymes)

DS diet= Detoxizyme -supplemented diet (contains mycotoxin targeted exogenous enzymes)

Table 3: Experimental diets layout

\begin{tabular}{lll}
\hline $\begin{array}{l}\text { Treatment } \\
\text { group }\end{array}$ & Diet & Exogenous enzyme component \\
\hline Control & $\begin{array}{l}\text { The control diet } \\
(100 \% \text { layer's ration })\end{array}$ & None \\
& $\begin{array}{l}\text { Fullzyme }+ \\
\text { FS Diet }\end{array}$ & $\begin{array}{l}\text { Protease, Amylase, Cellulase, Lipase, B } \\
\text { glucanase, Phytase, Pectinase, Xylanase. } \\
\end{array}$ \\
formulated ration & [Nutrient targeted exogenous enzymes $]$ \\
DS Diet & $\begin{array}{l}\text { Detoxizyme }+ \\
\text { formulated ration }\end{array}$ & $\begin{array}{l}\text { Epoxide reductase, Esterase, Hydrated Sodium } \\
\text { Calcium Alumi nosilicate (HSCAS), and. a }\end{array}$ \\
& & blend of specific natural detoxifying enzymes \\
\hline
\end{tabular}

Key

FS diet $=$ Fullzyme Supplemented diet (contains nutrient targeted exogenous enzymes)

DS diet $=$ Detoxizyme-supplemented diet (contains mycotoxin targeted exogenous enzymes) 

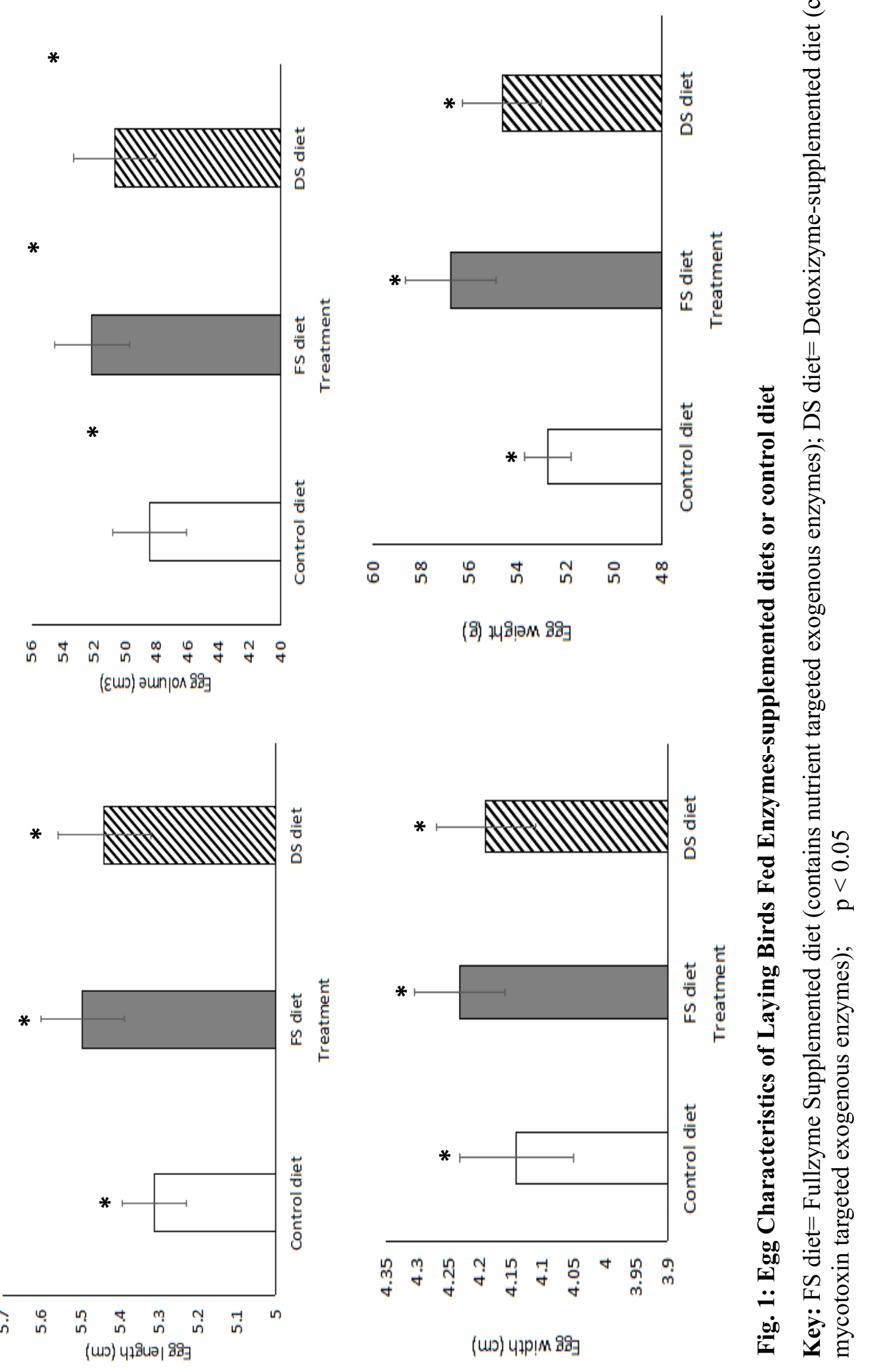
Fig. 1: Egg Characteristics of Laying Birds Fed Enzymes-supplemented diets or control diet.

FS diet=Fullzyme Supplemented diet (contains nutrient targeted exogenous enzymes)

DS diet= Detoxizyme-supplemented diet (contains mycotoxin targeted exogenous enzymes)

Egg length (a), Egg width (b), Egg volume (c), and Egg weight (d) were significantly different $(p<0.05)$ between diet groups. Eggs from FS diet group had the highest values followed by DS diet group and then the control diet group.

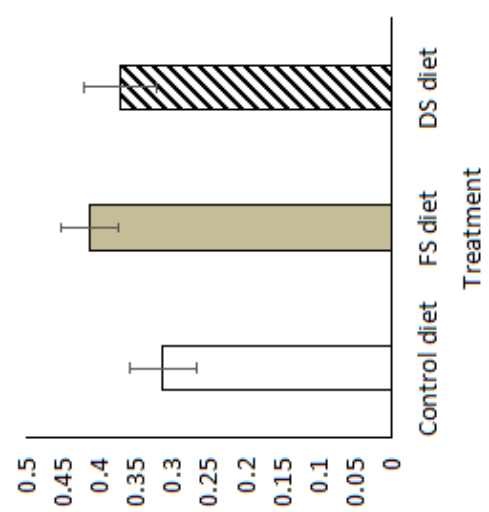

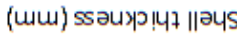

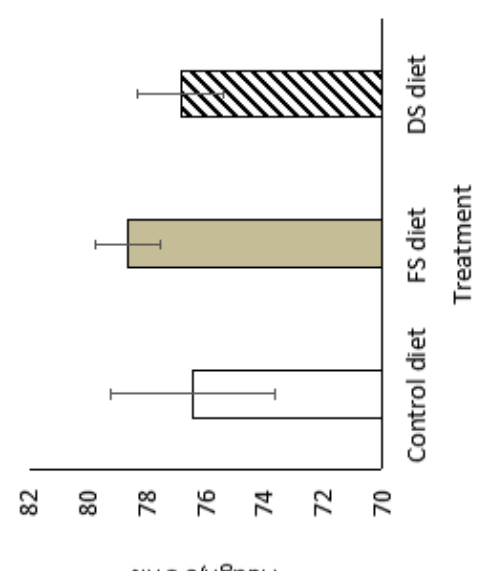

țuns.'บจิneH

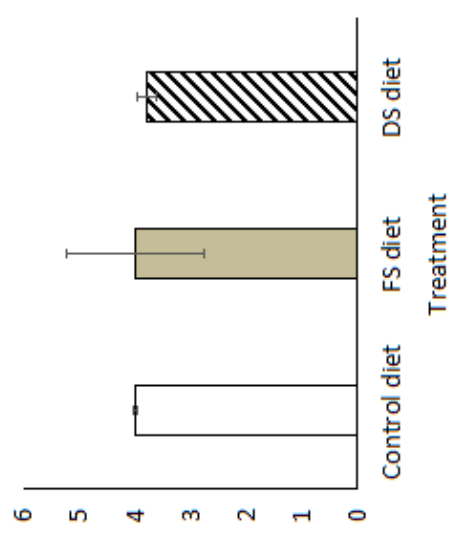

(uس) ॥əว
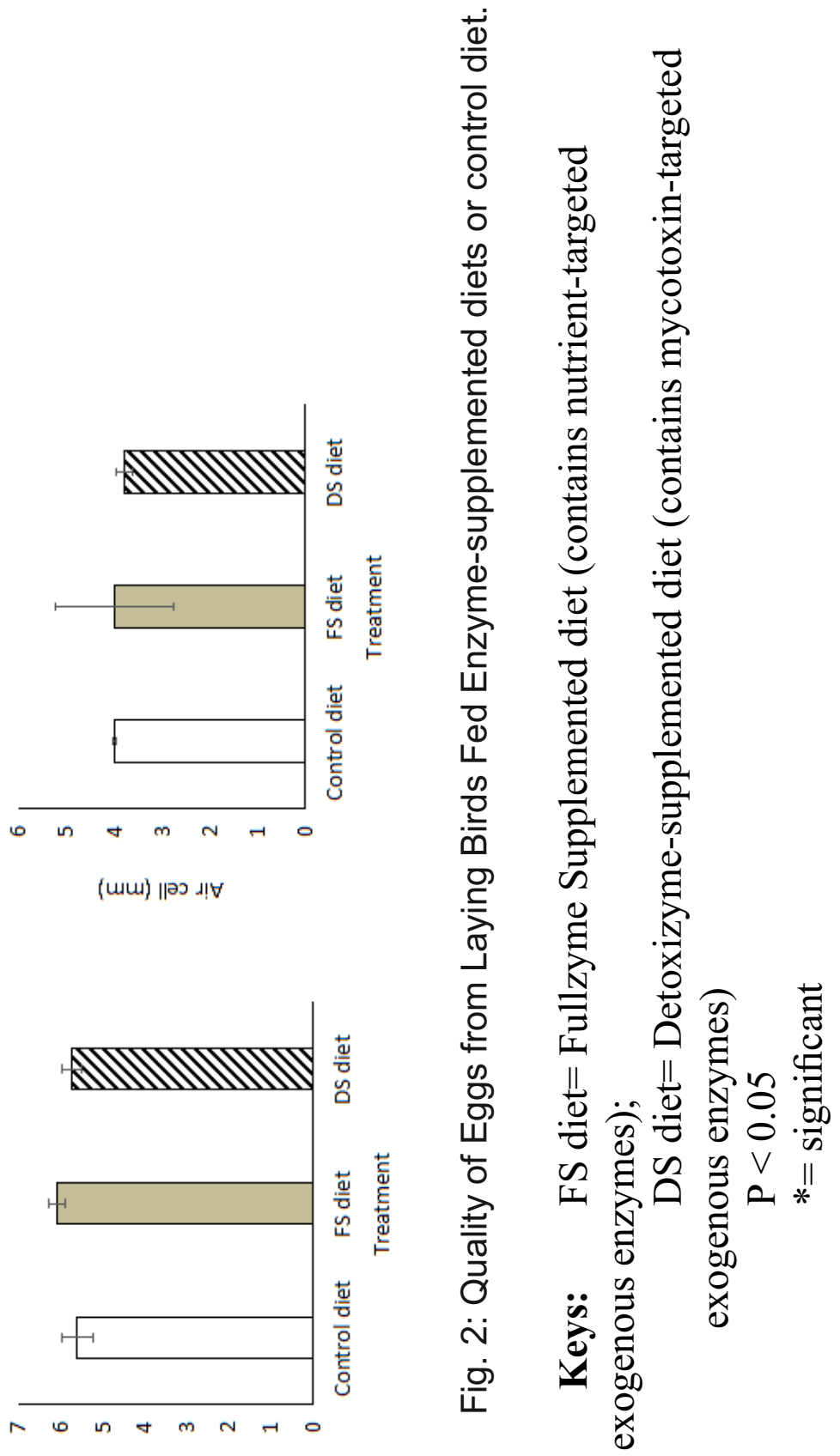

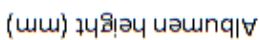


Fig. 2: Quality of Eggs from Laying Birds Fed Enzyme-supplemented diets or control diet

FS diet $=$ Fullzyme Supplemented diet (contains nutrient targeted exogenous enzymes) DS diet $=$ Detoxizyme-supplemented diet (contains mycotoxin targeted exogenous enzymes) Egg yolk diameter (a), Haugh's Unit (b), Shell thickness (c), Albumin height (d) and Air cell height (e).

All parameters except Air cell height were significantly different $(\mathrm{p}<0.05)$ between diet groups. Egg yolk diameter and Haugh's Unit values were highest in the FS diet group while DS and control diet groups had similar values. Shell thickness and Albumin height were highest in the FS diet group, followed by the DS diet group, but were least in the control diet.
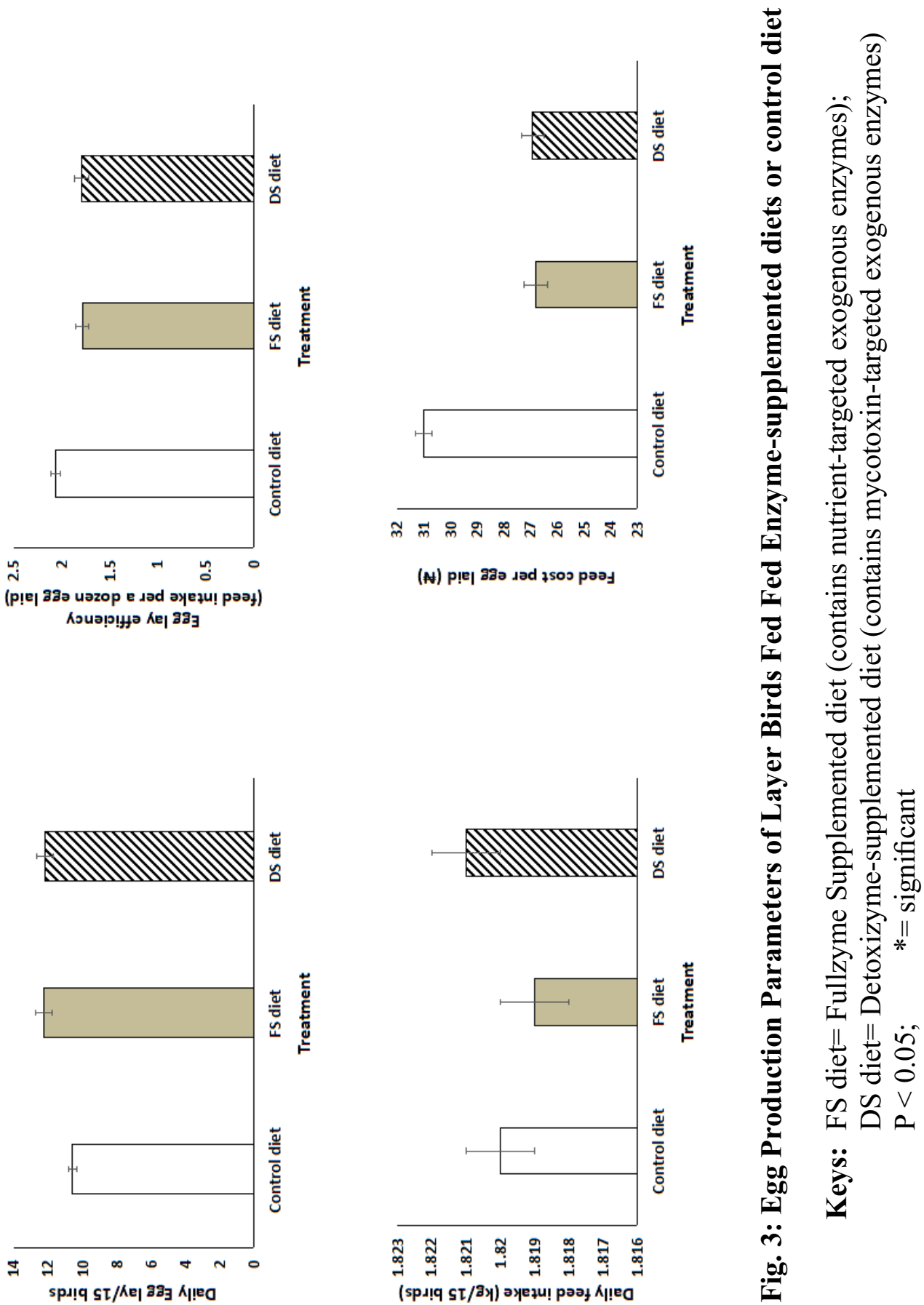
Fig. 3: Egg Production Parameters of Layer Birds Fed Fed Enzymesupplemented diets or control diet

FS diet $=$ Fullzyme Supplemented diet (contains nutrient targeted exogenous enzymes). DS diet= Detoxizyme-supplemented diet (contains mycotoxin targeted exogenous enzymes)

Daily egg lay (a), Daily feed intake (b), Egg lay efficiency (c), Feed cost per egg laid (d). All parameters were significantly different at $\mathrm{p}<0.05$. Daily egg lay was higher in birds fed the control diet than in birds fed FS or DS diets. The egg lay in the FS diet group was similar to the egg lay in the DS diet group. Daily feed intake was higher in the DS diet group than in the FS diet group but, feed intake in the control group was similar to DS and FS diet groups. Egg lay efficiency and feed cost per egg laid was higher in the control diet group than in the FS or DS diet groups. The Egg lay efficiency and feed cost per egg laid in the FS diet group were similar to that of the DS diet group.

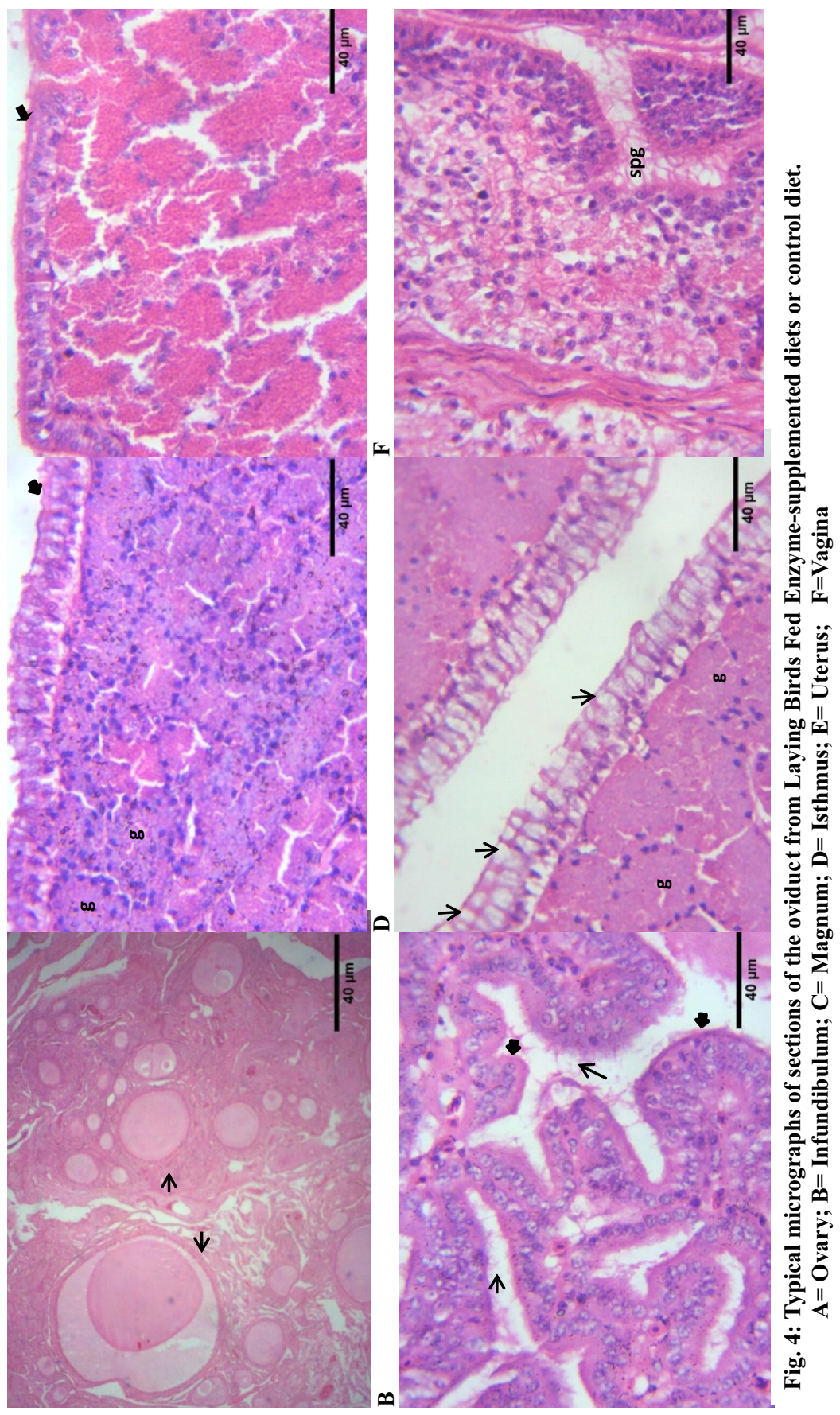


Fig. 4: Typical micrographs of sections of the oviduct from Laying Birds Fed Enzyme-supplemented diets or control diet.

FS diet=Fullzyme Supplemented diet (contains nutrient targeted exogenous enzymes) DS diet= Detoxizyme-supplemented diet (contains mycotoxin targeted exogenous enzymes)

Scale bar $=5 \mathrm{pixel} / \mathrm{um}$

Typical features of of Layer birds fed the control, FS, or DS diets. (A) ovary; egg yolks (arrow) at different stages of development. (B) Infundibulum; convoluted epithelial lining (block arrow), cells have cillia (thin arrow). C) Magnum; pseudostratified columnar epithelium(block arrow) and numerous basophilic glands ' $\mathrm{g}$ '. (D) Isthmus; numerous secretory epithelial cells (arrow) and fewer basophilic submucosal glands ' $g$ '. E) Uterus; pseudostratified cuboidal epithelium (block arrow). (F) vagina; showing sperm host glands 'spg'. 